\title{
ARTICLES
}

\author{
Marek Sobczyński
}

\section{Do we need state and what for? The role of the state in the modern World}

\begin{abstract}
The state is subject of interest to many scientific disciplines: constitutional and international law, sociology, philosophy, administrative and political sciences, social psychology, economics, political and economic history, military sciences, regional studies and, of course, political geography and geopolitics. In the course of history, from ancient to modern times, the state was defined in very different ways.

The author comes out in his deliberations from the analysis of the elements that make up the various definitions of the state. Then he reviews the classification of functions that the modern state fulfills and analyzes the way in which they are implemented in various countries around the world, trying to answer the question, is the state necessary for citizens and for what?

Finally, the author draws attention to the frequent undertaking of the subject matter of the functioning of the state in the world's belles-lettres in epic works and in dramas both in the past and nowadays.

The last issue raised in the paper is the analysis of the functioning of unrecognized countries, mainly European ones, and what are the consequences of their exclusion from the international community influencing the life of their inhabitants, economy and functioning of their societies.
\end{abstract}

Keywords: the role of the state, globalization, philosophy of the state.

\section{Introduction - how the definitions of the state have changed over time?}

The state is a subject of interest of many scientific disciplines: constitutional and international law, sociology, philosophy, administrative and political sciences, social psychology, economics, political and economic history, military sciences, regional studies and, of course, political geography and geopolitics. In the course of history, from ancient to modern times, the state was defined in very different ways. 
The definition of the state evolved with the appearance of different philosophical systems. It was based on changing elements or features of statehood, which determined the ways of which the complex socio-political structure of state was sought to be defined.

Let's try to recall certain stages of this process of defining the state.

The ancient Greek philosopher Plato (427-347 BC), an outstanding theoretician of the state, wrote down his views on this matter in 10 books. The ideal state according to Plato should strive to universality and permanence, should operate according to general and universal principles regardless of the conditions of its functioning; citizens should be steady in thinking and feeling, poets should be expelled from the city so they would not affect citizens by art. The state should have one goal for everyone; parts of the state should depend on the whole entity, because it's to be built like an organism, it must be based on knowledge; philosophers should be situated in the top positions as they possess the greatest knowledge. The state should be ascetic, because it aims to an ideal goal, the achievement of which does not provide citizens with any direct benefits, goods or even requires their renunciation; for the two higher classes of society, individual property is abolished; there is a communist system in which renunciation is common; the lowest class is not subjected to rigors because it does not participate in the pursuit of perfection.

Also in ancient Greece, Aristotle (384-322 BC) defined the state as "a community (organization) of various groups of people necessary for its existence" and, at the same time, a product of nature. The state in this view is a community of equals, i.e. only citizens performing military service and participating in representative assembles. For the existence of the state, non-citizens like peasants, craftsmen and all kinds of workers, were also needed.

In the circles of European Christian democracy very popular is the vision of the state proposed by Saint Thomas Aquinas (1225-1274), according to which "the state is a perfect community (societas perfecta) self-sufficient, independent and self-governing. The goal of the state is the common good (bonum commune), which is expressed in preserving peace and ensuring universal temporal happiness". The state, however, was supposed to arise as a result of the sin of people (Sidorkiewicz 2010: 216).

The famous German philosopher from Königsberg Immanuel Kant (17241804) considered the state as "association of number of people under the rule of law". Thus, the element of the rule of law as a civic duty appears in this definition.

The founder of the German philosophical school of panlogism Georg Hegel (1770-1831) defined the state as a "as a kind of God on Earth (absolute being)". In such a state, an individual can shape its identity and devote itself to the state.

It is also impossible to forget, especially in Central-Eastern Europe, about the existence of the Marxist ideology and its catastrophic impact on humanity. 
The German founder of this ideology, Karl Marx (1818-1883), proclaimed that "the state is a tool of the ruling class". True power has always been in the hands of the "owners of the means of production" or the bourgeoisie. Marxists believed that the state should be in the hands of a minority. The primitive societies, as they argued, did not create states, because all individuals had a common interest and there was no class system. According to Friedrich Engels (1950), this means that the minority is the basis of the state's dominance, because it is the only way to restore power to the people.

These thoughts were later developed in a criminal way by Vladimir Ulyanov alias Lenin (1870-1924), according to who "the state is a machine for maintaining the control of one class over another - a forced organization serving to the ruling class". However, the French writer Alexis de Tocqueville (1945), warned that the state will become selfish if one class decide to dominate the other classes.

The Polish philosopher, sociologist, and the theoretician of the state and law from the interwar period Czesław Znamierowski (1888-1967) defined the state as a "ruling organization normalized by constitution, indispensable for a community of larger number of members living on a larger territory". The goal of the state is to protect and defend members of this group and to maintain internal order. In the state there are: the ruling group and politically passive unorganized mass - the ruled.

Unfortunately, Znamierowski did not specify the size of the population and the size of the territory necessary for the existence of the state. Today we know that such criteria do not exist, as evidenced by the functioning of a state deprived of territory (State of the Order of Malta), by examples of numerous countries which do not control their territories (e.g. Palestine, the Sahrawi Republic), and country with a small population, below 1 thousand people, in addition not always possessing citizenship of this state (the Vatican).

The modern American definition of the state proposed by J. Roland Pennock and D. Gregory Smith defines it as "a social organization that has conclusive power over all people living in a certain territory, whose main goal is to solve common problems, to secure common goods, and most of all to maintain order".

And finally, according to Weber, Gerth and Mills (1946: 48), "the state is a human community that successfully demands a monopoly on the legal use of physical force in a given territory".

Let's therefore try to recapitulate the perception of the essence of the state on the basis of several disciplines of science.

On the basis of political sciences: "The state is a compulsory organization, equipped with the attributes of supreme power in order to protect against external and internal threats, providing to the community inhabiting its territory, composed of interdependent groups with diverse interests, the conditions of existence favorable to their economic strength position and political influence". 
On the other hand the modern functionalist philosopher Talcott Parsons (1967) views the state as an authoritative structure. He believes that authoritarianism is justified if it achieves a "social goal" on which society depends. He looks from the electoral perspective, where "the deposit of power" is revocable when the politician is not elected by voters in the next election.

For sociologists, "the state is the highest form of social organization, a great sovereign political institution controlling the area of a given country, involving all members of society or societies that inhabit its territory".

On the ground of international law, the Austrian-German lawyer Georg Jellinek (1851-1911), the author of the three-element concept of the state, argued that "the state is an organization of a nation settled in a specific territory, equipped with direct supreme authority" (Jellinek 1914: 144). For the existence of a state, a permanent population, a defined territory and sovereign power are necessary. In 1934, the Montevideo convention, added a fourth element to this definition - the ability to be legally recognized by the international community.

In this review we certainly cannot ignore the political geography. According to our colleague from Lodz Andrzej Suliborski and an outstanding Bulgarian political geographer Marin Bachvarov, "The state is a sovereign territorial entity acting in favour of political, economic, social and defence interests of its inhabitants" (Baczwarow, Suliborski 2002: 124).

\section{What is the function of the state in the modern world and how is it implemented in practice?}

According to the British political geographer David Storey (2001: 39), the state provides the legal framework, infrastructure and services to be used for the benefit of citizens.

In particular, the contemporary state fulfils the following functions:

- regulates the economy (however, there are theories postulating the maximum limitation of this function of the state),

- it provides public goods, such as health, education and transport services (though in many countries such services are currently privatized),

- it provides legal and other frameworks that guide the behaviour of citizens,

- it defends its territory and its citizens against external aggression and interventions (there are, however, countries that use only diplomatic means for their defence, and do not have armed forces in practice).

As you can see from among four basic functions of the state, as many as 3 are not always performed to the full extent. The only aspect that remains is the legal and social framework as an immovable pillar of state functions. However, there are countries that will not even fulfil this task in a proper way, e.g. Venezuela, Zimbabwe, Democratic Republic of the Congo, and unfortunately also closer to us Hungary and Poland. 
In a large number of countries around the world, citizens have daily contact with the state. The post office, telegraph and telephone are mostly state institutions or stay in the hands of companies controlled by the state. The police are almost always state-owned, the same as the justice system. The issue of money is the exclusive privilege of a national bank, a state institution. The state organizes and equips armed forces, and often also legally obliges citizens to perform military service. In 1979, however, the United Kingdom initiated the process of privatization of certain spheres which until now have been the domain of the state. This process was followed later by other highly developed Western countries. Rail transport and water supply systems have been privatized. This process of so called "state rolling up" leads to minimizing the contact of the citizen with the state.

The role of the state in contemporary societies is to deal with the current problems of its citizens regardless of the geographical region, identity and culture. The features of the state combine the idealistic, functionalistic and organizational perspective, because they are compatible with its ubiquity, private and public sectors, legitimacy, domination and territorial aspects. This commitment is characterized by at least three bases; increasing number of interpersonal bonds (creating the world network), studying of the pace and depth of human evolution (history) and combining anthropological and ecological transformations (social, cultural, economic and technological).

There are many different types of countries. The most numerous are unitary states, in which power is centralized, there are a few federal states with a high level of political decentralization. There are authoritarian states with a fairly extensive control function and a low degree of social participation, but there are also more open state systems, symbolized by liberal democracies characteristic for the Western world. In a simplified way, there is a tendency to think about the relations between the state and the citizen as a freely introduced set of assignments. In fact, it does not occur in authoritarian states. Even in the so-called liberal democracies, where the electoral system ensures transparency, there are strivings to delve into the superficial appearance of the state as a repository of the collective will of its citizens to develop appropriate theories regarding the role and function of the state.

A very interesting illustration of the diversification of the level of democratization of individual states is the democracy index (Fig. 1). Its highest level was reached by the Scandinavian countries, and the British dominions Australia, New Zealand and Canada. The position of the United States (the same as India) is a very surprising and only slightly ahead of Poland. The worst state of democracy prevails in the belt of Central Africa, the Northern Korea, and Laos, the two Asian post-Soviet republic of Turkmenistan and Tajikistan, Syria, Yemen and Saudi Arabia.

In modern societies, the state is ruled by common ideologies, although there is a fundamental difference between the state and the government. Martin Wolf (2010) confirmed that the primary goal of the state is protection. However, 


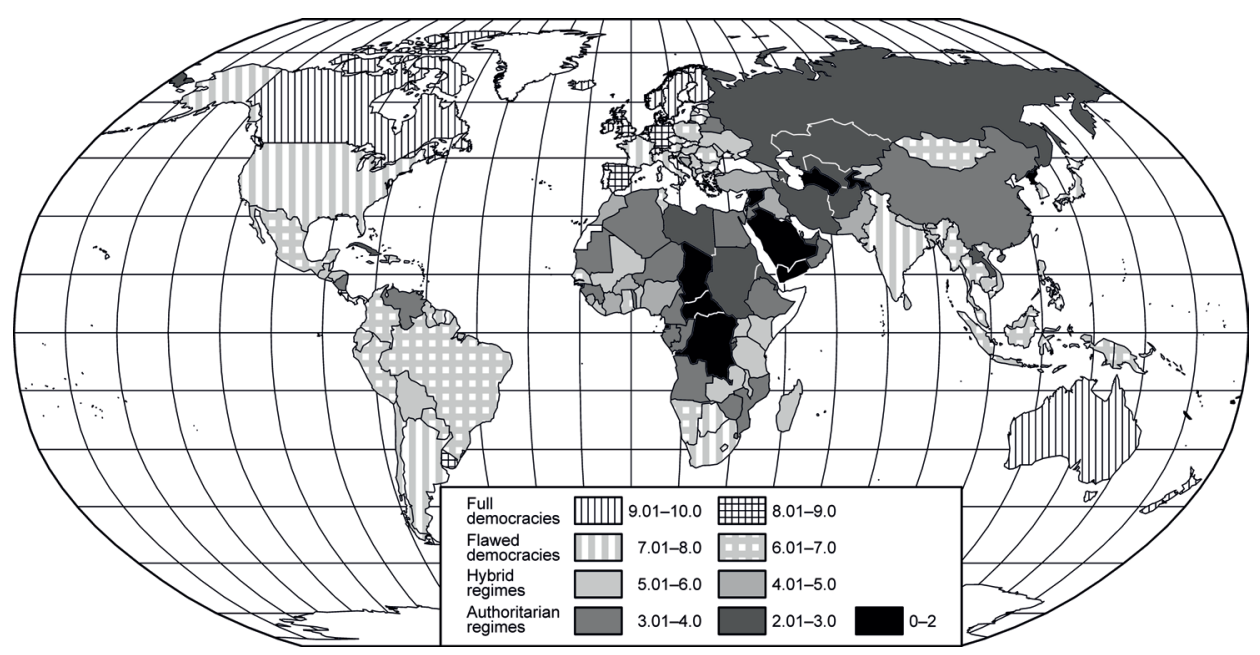

Fig. 1. The democracy index in 2018

Source: https://en.wikipedia.org/wiki/Democracy_Index [3.03.2019].

anarchists believe that state protection is pointless and one can rely on voluntary programs such as the social police. On the other hand, there is a common belief that the majority of citizens voluntarily recognize state protection against all factors that may destroy or harm them, both internally and externally.

Mancur Olson in the book Power and prosperity wrote that the state is a "stationary bandit", not a "wandering bandit". The "wandering bandit" has little interest in improving the economy, but the "stationary bandit" is looking for all possible means to develop citizens, and the state authorities always try to draw from the generated surplus controlled by them.

According to the Encyclical Pacem in Terris, the role of the state is to try to solve all problems. This may include changes in legislative conditions, changes in the constitution and changes in the moral standards of the state and its citizens. Moreover, authorities must govern society with discretion and make decisions with full knowledge of the law. The social agency of the state is to maintain some form of power through the appropriate bodies; this is done through moral and civil control. Democracy is further developed to facilitate citizenship education and to maintain public order and peace. The government's role in the political sphere is to intervene in public authorities, such as the political and legal structure of the state.

In the subject literature one can find numerous proposals for classifying the functions of the state (Sidorkiewicz 2010: 220).

Taking as a criterion the directions of the state's activity in relation to other political systems, one can distinguish following functions: adaptive, regulatory and innovative. 
The adaptive function is associated with the process of adapting the activities of the state, its organs and structures to the changing reality (economic, social or cultural).

The regulatory function aims to develop specific rules for the organization of the state. The supreme thing is to maintain internal order in the state. Caring for an internal structure contributes to greater integrity. It is very important in this case to create good law.

The innovative function is based on the process of changes that are introduced into the state institutions. Indication of the direction of these changes or their initiation is a key issue. New elements may appear in the system (change in the ownership structure, modernization) that affect the system's changes or the rules of its functioning.

From the point of view of the universal directions of the state's activity, one can distinguish its functions: creation of norms, distribution of goods and values, and organizing function (Storey 2017).

According to the criterion of the spatial extent of the state's operation, two types of functions can be distinguished: internal and external (Sidorkiewicz 2010: 222). This division has already appeared in Aristotle.

The internal function aims at achieve and maintain social order within the state organization and it includes following activities: legislative, order, administrative, economic-organizing, social and cultural-educational. The external function includes border protection and international policy (Dudek et al. 2013: 6).

Almost all countries are trying to effectively protect their territory and maintain military forces for this purpose. There are, however, some exceptions (altogether 21 countries), and these are not only so-called micro-states, whose armed forces are equally microscopic and in practice do not guarantee them any defense. The Iceland does not have any army, however it is a member of NATO guarantying the defense of its territory. The possession of a regular army has also been renounced by a number of countries, including Costa Rica, Panama, Haiti, Mauritius, Solomon Islands and Vanuatu. In Europe, besides Iceland, Andorra, Liechtenstein, the Vatican and Monaco also have no army.

The scope of the internal functions of the state can be very diverse. This can be illustrated in a few examples.

An interesting example is the structure of state expenditure on the protection of citizen's health in 2014 (Fig. 2). In general, the percentage share of expenditure on health care in the total state budget reaches the highest values in the so-called highly developed countries (blue on the map, namely USA, Japan, New Zealand, the Netherlands and Switzerland - these are not surprising) but such countries as Uruguay, Nicaragua and Costa Rica stand out from this background. The low level of health protection in Libya, Cameroon, Eritrea and South Sudan, Pakistan Myanmar and Laos is also not a surprise, but again the position of oil-rich Azerbaijan is a negative surprise. 


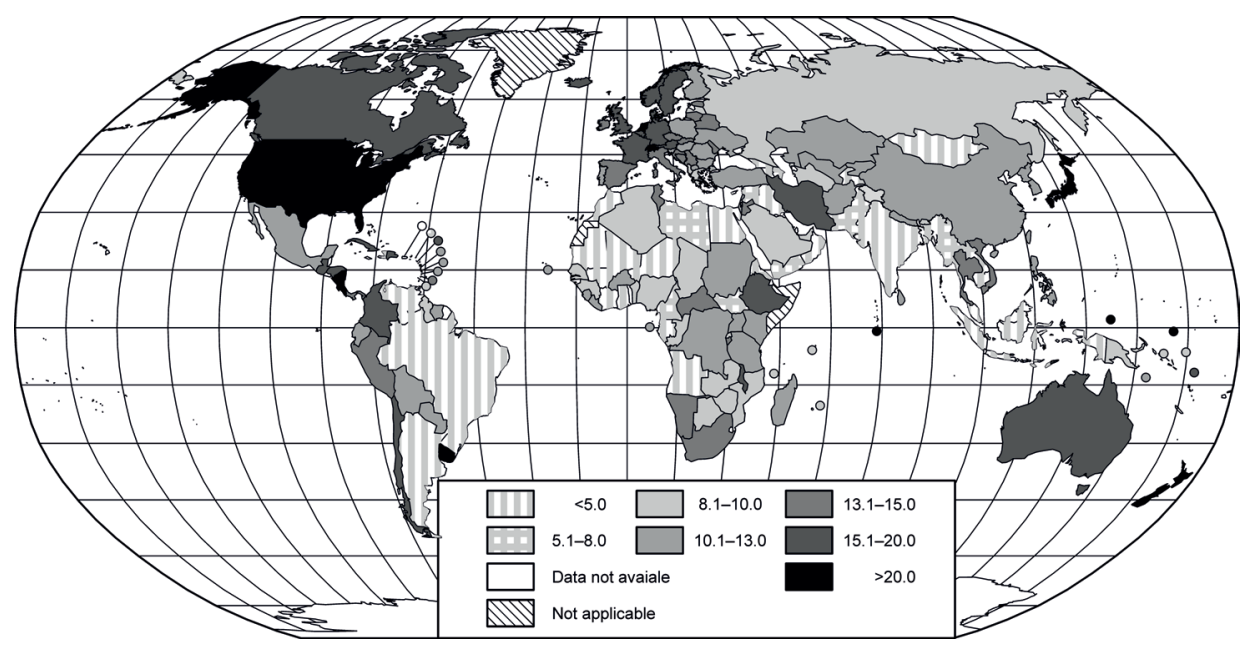

Fig. 2. Governmental expenditure on health in 2014 as a percentage of the total government expenditure

Source: WHO Statistics.

The Human Development Index (HDI) in 2017 is a very good measuring instrument of comprehensive state care over the citizen. It is dominated by two countries of North America (United States and Canada), four Pacific states (Australia, New Zealand, Korea and Japan), the Benelux and Scandinavian countries and Ireland, the United Kingdom, Germany, Austria Switzerland and Israel. At the other extreme of the HDI are almost all of Africa and a large part of Asia (Fig. 3).

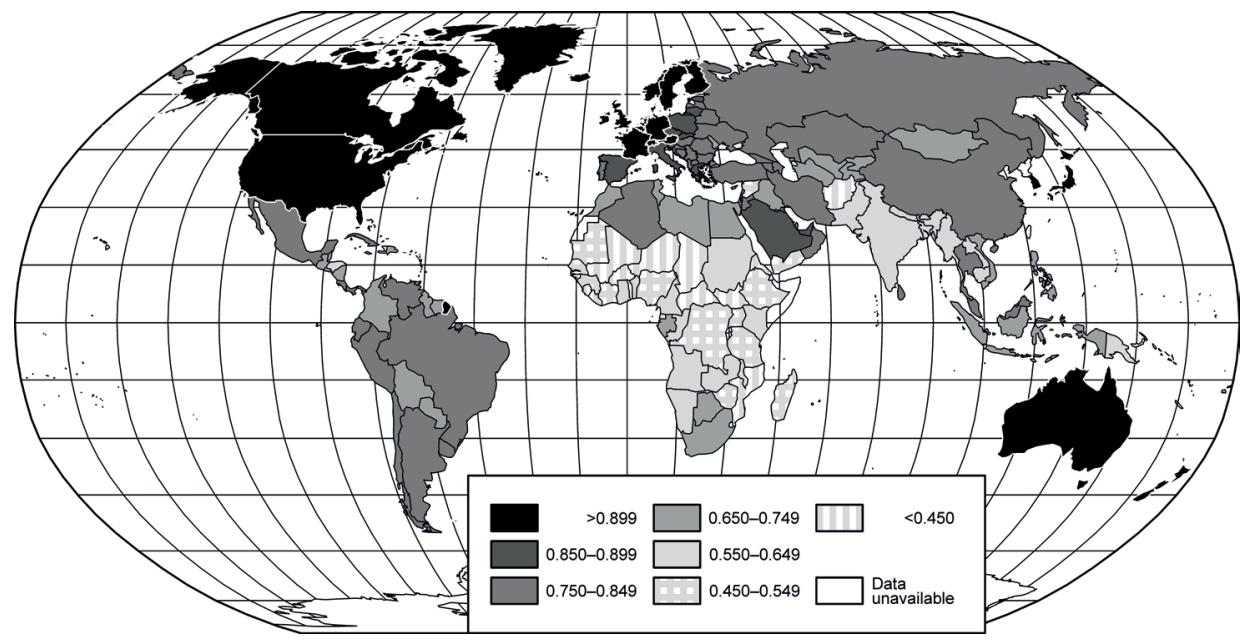

Fig. 3. Human Development Index in 2017

Source: https://en.wikipedia.org/wiki/Human_Development_Index [3.03.2019]. 
Another measure of the level of democracy in economic terms is the index of economic freedom, which shows a picture quite different from the one expected (Fig. 4). The fact that North Korea, Myanmar and other dictatorships strongly restrict the freedom of economic activity is not a surprise, but the positions of Ukraine, Argentina, Iran, Brasil and India are surprising. Full economic freedom prevails only in the South Pacific and in Switzerland. The position of Botswana and Jordan (equal to Poland) is surprising.

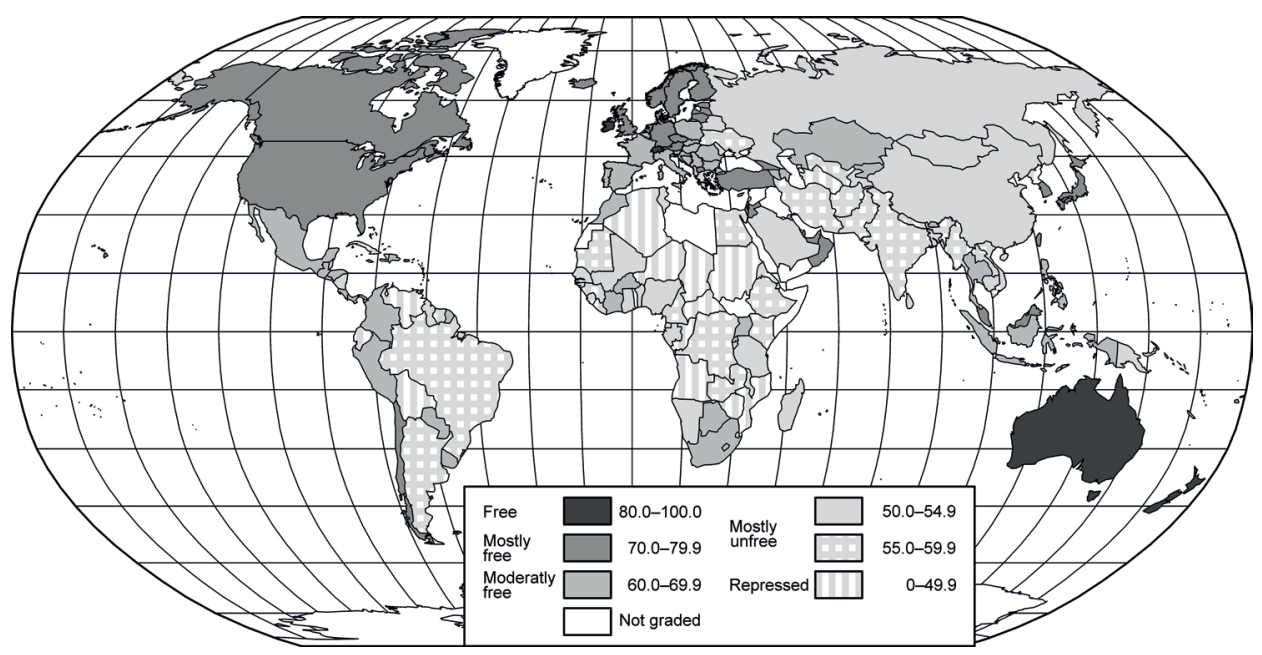

Fig. 4. Index of the Economic Freedom 2018

Source: https://en.wikipedia.org/wiki/Index_of_Economic_Freedom [3.03.2019].

Even in the group of the most developed countries in the world, social care is strongly diversified, as its shown on the graph for the OECD countries presenting the share of retirement in the level of wages (Fig. 5). Retirement that the Dutch can get is close to $90 \%$ of their former salary, which is over three times better than that offered to the British (22\%). It is interesting to note the very modest offer of the government of the United States (retirement pension is $40 \%$ of the salary) of Ireland and Japan for its citizens. Poland, despite of being a former socialist state with the long tradition of broad social assistance, is already at the bottom of this chart, while Slovakia and Hungary are still in the upper half.

The last analyzed indicator is the percentage of help for mothers who gave birth to a child covered by state aid (Fig. 6). High (over 90\%) is in parts of Europe, including Scandinavia and former communist countries of Central Europe, as well as in Greece (as we know today overgrowing possibilities of its government) and in New Zealand. It is shocking that only two countries do not give help to the mother of the child, one of them is Papua New Guinea are the second is United States. 


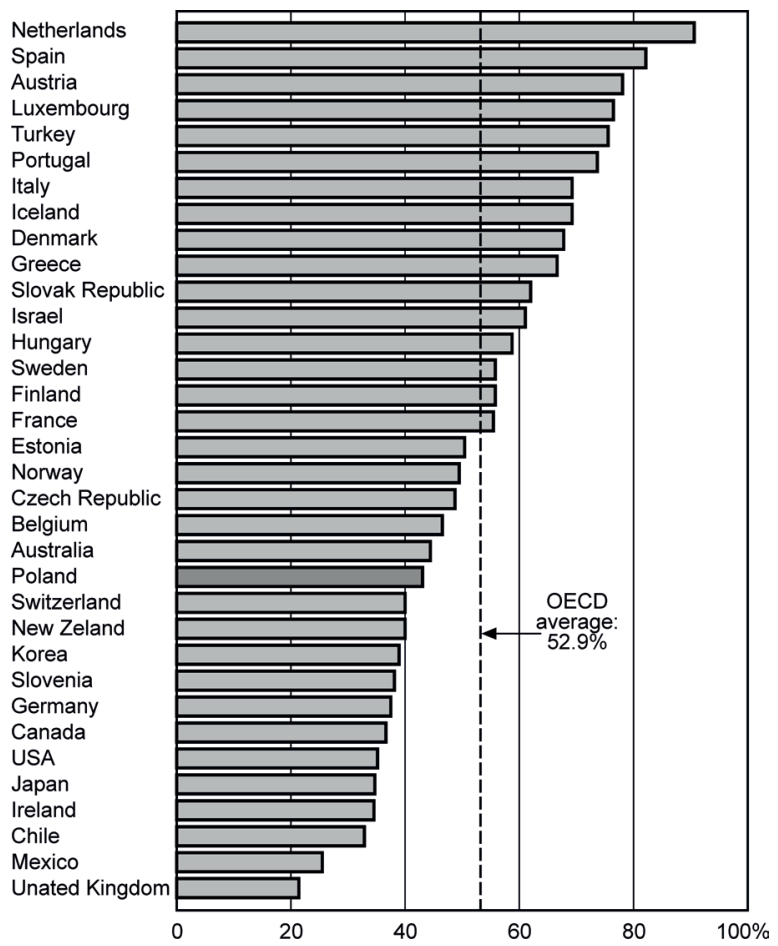

Fig. 5. Social security benefits as a percentage of earnings in OECD countries in 2015 Source: own elaboration.

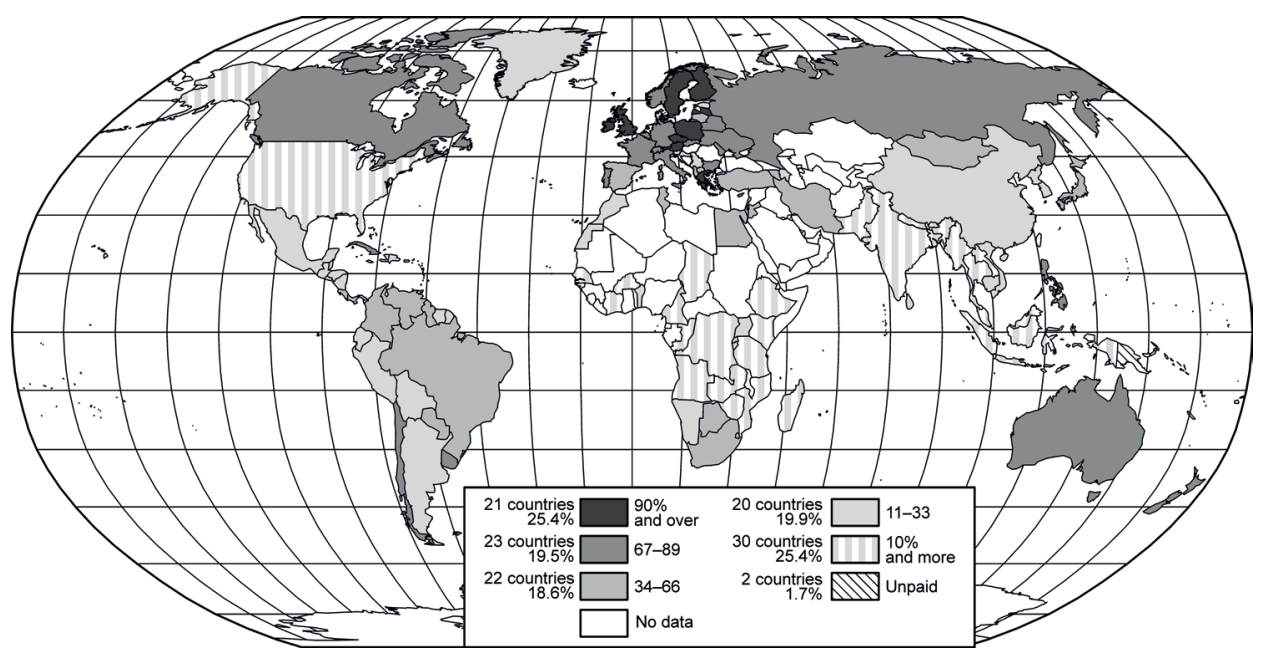

Fig. 6. Governmental support to mothers who gave birth to a child (2018) Sources: WHO. 


\section{The image of the state in belles-lettres}

The essence of the state is of interest not only to political scientists or historians but also to writers and poets. The topos of the state as a social institution appeared in numerous works of belles-lettres. Already ancient philosophers in their treatises, dramas or poems have often referred to the functioning of states. As examples, you can recall works such as: Sophocles Antigone or Plato's State. In modern times, the works of Utopia by Thomas More, On the spirit of the laws Montesquieu's (Charles Louis de Secondat), The Prince by Niccolo Machiavelli, The tragedy of Macbeth by William Shakespeare were particularly important.

The books of Nineteen-eighty four and the Animal farm of George Orwell and The trial and The castle of Franz Kafka are considered as symbols of literature devoted to the exercise of power. The essence of power and state affects world-famous works Breve new world of Aldous Huxley and Fatelessness by Imre Kertész, or the work of the Soviet dissident Alexandr Solzhenitsyn - The Gulag archipelago.

Politics, state and government system play a particularly important role in the Ibero-American literature. Writers and poets were at the forefront of revolutionary movements (Jose Marti in Cuba, Jorge Amado in Brazil), and sometimes they also exercised power (Sergio Ramirez vicepresident of the Nicaragua). Numerous references to politics and the role of the state can be found in the works of such writers and poets as: Echeverría Estéban, Jorge Borges, Julio Cortazar, Carlos Fuentes, Osvaldo Soriano, Pablo Neruda, Gabriel Garcia Marquez, Alejo Carpentier, Juan Carlos Onetti, Mario Vargas Llosa.

Also in Polish literature, one can find many works politically engaged which refer to the essence of the state and power. The outstanding examples are: $A$ brief discussion among three persons: a lord, a commune chief, and a priest of Mikołaj Rey, The dismissal of the Greek envoys of Jan Kochanowski, On the improvement of the Commonwealth of Andrzej Frycz Modrzewski, The Sejm sermons of Piotr Skarga, The return of the deputy of Julian Ursyn Niemcewicz, and Konrad Wallenrod of Adam Mickiewicz. After regaining independence in Poland in the inter-war period, the subject of state continued to be discussed in Stefan Żeromski's works The labors of Sisyphus and Seedtime. In the period of communism, when it was not impossible to criticize the totalitarianism of communism, appeared books by Ryszard Kapuściński showing the absolutist systems in Ethiopia (The emperor) and Iran (Shah of shahs). There were also books published in the underground or on emigration like The captive mind of Czesław Miłosz, The world apart of Gustaw Herling-Grudziński, Tango of Sławomir Mrożek and My century of Aleksander Watt. 


\section{Non-recognized states and consequences of this fact for their citizens}

The importance of efficient functioning of the state for its citizens can be assessed by analyzing several examples of countries that are de facto existing but are not recognized by the international community. The criterion of non-recognition is not only the fact of absolute lack of recognition, because there are only five such cases (Transnistria, Nagorno-Karabakh, People's Republics of Donetsk and Luhansk and Somaliland), but also cases of countries enjoying only a trace recognition (Turkish Republic of Northern Cyprus - recognized by Turkey and Abkhazia and South Ossetia recognized by 5 countries in the world, including Russia and Syria) (Fig. 7).

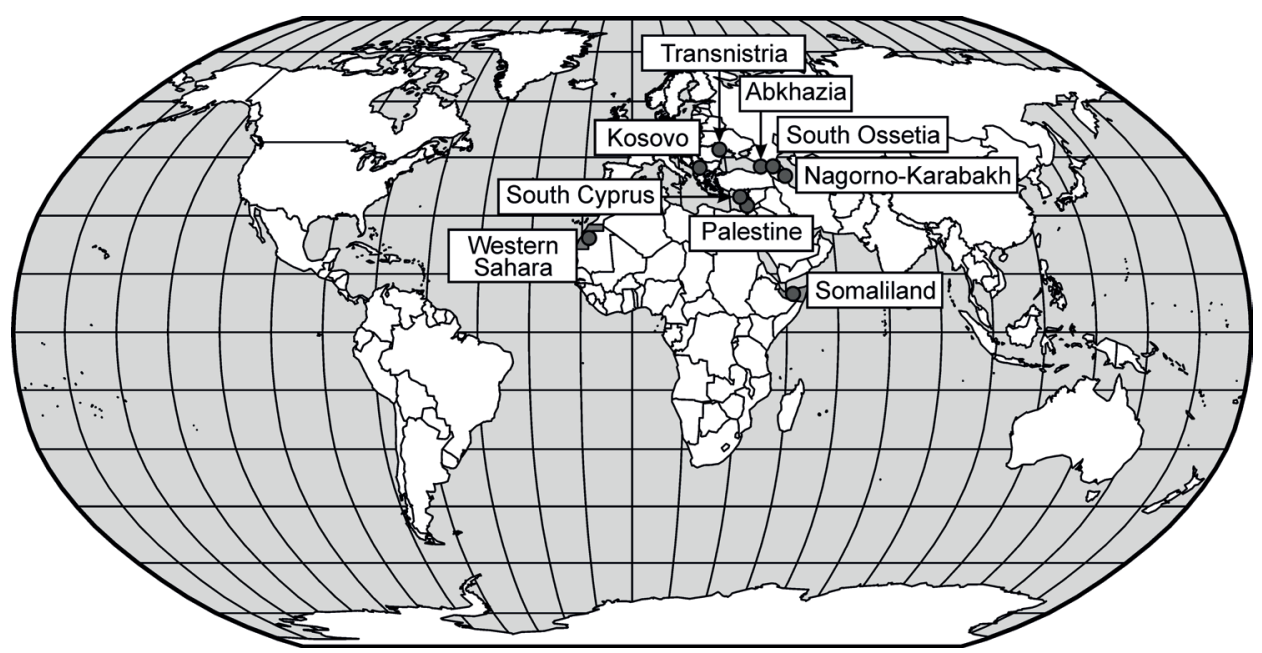

Fig. 7. Non-recognized states

Source: own elaboration.

Most of these countries owed their independent existence to the victorious wars which resulted in separation from another country (e.g. Moldova, Georgia, Azerbaijan, Cyprus, Ukraine). Only Somaliland had disconnected from Somalia without a fight during the disintegration of the state but then had to fight against the other units that emerged in parallel with Somalia (e.g. with Puntland, which, in fact, is independent but did not declare its independence, as Somaliland did). This means that their infrastructure has been damaged in the course of the wars and in almost all cases has not been completely rebuilt until today.

The status of unrecognized states is not ephemeral, but seems to be permanent, as it has lasted for 43 years in Northern Cyprus, 28 years in Transnistria, 27 years in Somaliland, Nagorno-Karabakh and South Ossetia, for 26 years in Abkhazia 
and only for 4 years in case of republics in the east of Ukraine. In the first case, already two generations, in the other five cases one generation, were born in non-existing countries.

In another situation are the citizens of countries that enjoy a trace of international recognition, but the recognition by the immediate neighbour is crucial.

Abkhazia has its own currency (apsar) but it is only issued in the form of commemorative coins, whereas the Russian ruble is in circulation. The Russian ruble is the currency of most post-Soviet non-recognized states, including the Donetsk and Luhansk republics, with the exception of Nagorno-Karabakh, where the Armenian currency (dram) is on operation and Transnistria, which issues its own ruble. In 2004 Poland received and accomplished the order for the production of coins for Transnistria (treating them as tokens) (Krause 2013; Czubik 2009: 133). In Northern Cyprus the currency is Turkish lira.

The Abkhazian-Georgian border was closed for a long time (Szczerek 2011). Both countries, Abkhazia (Apsny) and South Ossetia (Hussar Iryston), belong to the Russian economic zone, are based on energy supplies from Russia and are protected by the Russian army. They are, therefore, a de facto part of Russia, just like after 2014 Crimea, which independence lasted only 24 hours. Abkhazia, once a Russia's Black See Riviera, today also counts on tourists but only from Russia and its revenues are much smaller than in the times of belonging to Georgia. An important export product is wine. South Ossetia has never been a tourist region and exists only thanks to Russian subsidies, as it practically does not have its own economy.

The passports of these countries allow their citizens to cross the border with Russia, otherwise they are useless, because they rather do not take trips to Venezuela, Nicaragua or Nauru. However, for a trip to other European countries, for example, they must obtain a passport of universally recognized states, therefore most often they apply for citizenship of Russia.

The actual political status of unrecognized countries is also different. With the exception of Somaliland, which has all the characteristics of a sovereign entity, all the others are at least protectorates if not colonies of the metropolises with which they are actually associated (Russia, Armenia and Turkey). In all these cases (with the exception of Somaliland), the aggressor's troops which led to their secession are stationing on their territory.

Only North Cyprus is in a relatively good economic situation, probably better than Turkey itself. All other countries are in a deep economic crisis, or, as in the case of eastern Ukraine, they have only grey economy, because they are the front zone.

Lack of recognition of the state plays an important role in private/internal law. The unrecognized states exercise real control over the area and population living in it, and introduce their own legal and judicial system. Economic and civil trade with these units is a necessity and intensifies the longer they exist (Czubik 2009: 121). 
The International Court of Justice's regulations concerning relations with de facto regimes or with the belligerents are applicable here, but there are no universal rules established and each state decides about the form of these relations. In the most difficult situation are the countries neighboring the unrecognized state, because in principle they cannot ignore its existence. The relations with the former metropolis and its attitude towards secessionist units are also important. Georgia rejects the existence of countries detached from it by force and Poland treats them in the same way because of friendly relations with Georgia. Syria, on the other hand, recognized both countries in 2018. Despite of the lack of recognition of Transnistria, Poland is one of its main (apart from Russia) trade partners, because the relations from the communist period between these two are still lasting, for example in the steel industry in Rybnica. The Sheriff Company of Tiraspol, dominating in Transnistria, is an importer of goods from Poland. Even Transnistrian authorities include people of Polish descent (Kosienkowski 2012). In August 2018 it was also revealed that the Polish government is importing anthracite from the Donetsk Republic, which was opposed by Ukraine.

\section{Conclusions}

States provide a policy framework that regulates (directly or indirectly) many aspects of our lives. Through the idea of the nation, they also play a key role in shaping identity and promoting a sense of community with potentially positive or negative implications (Storey 2017: 121).

Despite their apparent stability, states are not immutable units. They are historically conditioned by the territory (and the life of people on it) that they control. States are not only founded, they are being created and reproduced, and sometimes they are also subjected to challenges and fall. Through various state institutions and agencies, we begin to think territorially and this strongly focused approach to the state serves to rectify the current political and territorial structure. However, countries are not and have never been carefully limited spatial structures. They can still be perceived as dynamically developing individuals shaped by social interactions, economic, cultural and political activity. Despite all global international connections, the state and the idea of its sovereignty do not seem to be in decline. Recognizing its disputable character, the prognosis of the fall of the state and the arrival of a world without borders, still seems a very distant fact. While money flows relatively freely across international boundaries, many people (depending on who they are, where they come from and where they are trying to go) encounter a deterrent infrastructure at border crossings representing a hostile face of the state controlling its territory. 


\section{References}

Baczwarow M., Suliborski A., 2002, Kompendium wiedzy o geografii politycznej i geopolityce. Terminologia, Wydawnictwo Naukowe PWN, Warszawa.

Czubik P., 2009, Dokumenty z państw nieuznawanych $w$ obrocie cywilnoprawnym, "Problemy Współczesnego Prawa Międzynarodowego, Europejskiego i Porównawczego", 7: 119-133, http://www.europeistyka.uj.edu.pl/documents/3458728/cfcdddd8-0d15-4c0a-9784-837dad36db8f [22.08.2018].

Dudek D., Husak Z., Kowalski G., Lis W., 2013, Konstytucyjny system organów państwa, C.H. Beck, Warszawa.

Jellinek G., 1914, Allgemeine Staatslehre, wyd. 3, Verlag O. Häring, Berlin.

Kosienkowski M., 2012, Polska i Naddniestrze. Czas na wspótpracę?, "Nowa Europa Wschodnia", http://www.new.org.pl/1125-polska-i-naddniestrze-czas-na-wspolprace [22.08.2018].

Krause F., 2013, (Nie)istniejące państwa, "Po Przecinku”, https://poprzecinku.pl/art/ nieistniejace-panstwa/174 [20.08.2018].

Parsons T., 1967, Sociological theory and modern society, Free Press, New York.

Sidorkiewicz K., 2010, Współczesne ujęcie funkcji państwa, "Studia Elbląskie", 11: 215-229.

Storey D., 2001, Territory: the claiming of space, Prentice Hall, Harlow.

Storey D., 2017, States territory and sovereignty, "Geography”, 102 (3): 116-121.

Szczerek Z., 2011, Państwa których nie ma. W Europie sa takie cztery, "Światowidz. Inne widzenie świata", http://swiatowidz.pl/2011/09/panstwa-ktorych-nie-ma-w-europiesa-takie-cztery/ [20.08.2018].

Weber M., Gerth H., Mills C. Wright, 1946, From Max Weber: Essays in sociology, Oxford University Press, New York.

Wolf M., 2010, What is the role of the state?, "Economist's View", https://economistsview.typepad.com/economistsview/2010/09/what-is-the-role-of-the-state.html [23.07.2019].

\section{Czy potrzebujemy państwa i do czego? Rola państwa we współczesnym świecie}

Zarys treści: Państwo jest przedmiotem zainteresowania wielu dyscyplin naukowych: prawa konstytucyjnego i międzynarodowego, socjologii, filozofii, nauk administracyjnych, nauk politycznych, psychologii społecznej, nauk ekonomicznych, historii politycznej i gospodarczej, nauk wojskowych, regionalistyki i oczywiście geografii politycznej oraz geopolityki. W toku dziejów, począwszy od starożytności po czasy współczesne, państwo było bardzo różnie definiowane. Autor wychodzi zatem w swych rozważaniach od analizy elementów składających się na różne definicje państwa. Następnie dokonuje przeglądu klasyfikacji funkcji, które pełni współczesne państwo i analizuje sposób, w jaki są one realizowane w różnych krajach na świecie, próbując odpowiedzieć na pytanie: do czego państwo jest potrzebne obywatelom? 
Następnie Autor zwraca uwagę na częste podejmowanie tematyki funkcjonowania państwa w światowej literaturze pięknej zarówno w utworach epickich, jak i w dramatach zarówno w przeszłości, jak i obecnie.

Ostatnim zagadnieniem podjętym w wystąpieniu jest analiza funkcjonowania państw nieuznanych, głównie europejskich i konsekwencje faktu ich wykluczenia ze społeczności międzynarodowej dla życia ich mieszkańców, gospodarki i funkcjonowania ich społeczeństw.

Slowa kluczowe: rola państwa, globalizacja, filozofia państwa.

Marek Sobczyński

University of Lodz, Poland

Faculty of Geographical Sciences

Department of Political and Historical Geography and Regional Studies

e-mail: marek.sobczynski@geo.uni.lodz.pl 